\title{
秋田県女潟における花粉分析的研究"
}

\author{
辻誠一郎 ${ }^{21} \cdot$ 日比野紘一郎 ${ }^{31}$
}

\section{Pollen Analytical Studies of the Megata Peatland in Akita Prefecture}

\author{
Sei'ichiro TsujI ${ }^{2)}$ and Kōichiro HiBINo ${ }^{3)}$
}

\begin{abstract}
The paucity of reports on the vegetational history of the alluvial peatland overlooked the Japan Sea in Tohoku district encouraged us to study it. In this paper the pollen analytical features of the Megata peatland situated at an altitude of above $10 \mathrm{~m}$ in Akita Prefecture are described with a view to discussion of the vegetational history in the peatland and its surroundings from $3,500 \mathrm{y}$. B.P.

The results are summarized as follows.

1. The profile at the north of the peatland from which samples were taken for pollen analysis was mostly composed of autochthonous peat, of which the ages were calculated to be $3,180 \pm 85 \mathrm{y}$. B.P. $(\mathrm{N}-2003)$ at the $500 \mathrm{~cm}$ depth and $2,080 \pm 80$ y. B.P. $(\mathrm{N}-2004)$ at the $300 \mathrm{~cm}$ depth on the basis of ${ }^{14} \mathrm{C}$ dating.

2. Pollen diagram derived from peat profile is characterized by the occurrence of Cryptomeria, Fagus, Quercus and Alnus with a high frequency of pollen and a gradual increasing of Cryptomeria from 3,000 y.B.P. of the initial layer. In pollen diagram three pollen assemblage zones on the basis of the prosperities of these dominant genera are differentiated as follows:

I) Fagus-Quercus-Alnus zone $(630-420 \mathrm{~cm})$

II) Cryptomeria-Fagus-Quercus-Alnus zone $(420-70 \mathrm{~cm})$

III) Pinus-Cryptomeria-Alnus zone $(70-0 \mathrm{~cm})$

3. The pollen diagram suggests a gradual change from the forests dominated by Fagus and Quercus, to Cryptomeria-Fagus forests now found locally in Akita Prefecture. An increasing of Pinus and Cryptomeria at the zone III seems to be influenced by plantation in the neighbourhood of the peatland.
\end{abstract}

\section{I. はじめに}

東北地方において後水期の植生变遷拉よび気候变化を 究明するために今日まで多くの花粉分析がなされている が，これらの多くは亜高山帯预よび山地帯に分布する湿 原堆積物安との対象として扔り, 平野部の堆積物を対象 としたものは極めてそしい。ことに日本海側の平野部は 山崎 (1954)，堀（1959）の報告があるのタでほとえど
空白の状態にある・神保（1965）の言孛待つまでもなく こうした空白の地域に打いて詳細な花粉分析を行なうこ とは，原植生の復原打よびその地域の植生変遷を明らか にする上で今日に残された重要な課題である。本報では こうした観点に立って，秋田平野北部に位置する女潟の 湿原堆積物の花粉分析結果を報告し，この地方の森林お よび女潟の湿原植物の変遷について, 若干の考察を試み る.

1) 1975 年 5 月 6 日受付

2) 日本大学交理学部応用地学教室. Institute of Applied Earth Science, College of Humanities and Sciences, Nihon University.

3) 東北大学理学部生物学教室. Biological Institute, Faculty of Science, Tohoku University. 


\section{II. 女潟周辺の地形および植生}

女潟 (海抜 $10 \mathrm{~m}$, 北緯 $39^{\circ} 49^{\prime}$, 東経 $140^{\circ} 4^{\prime}$ ) は秋田 市の北方約 $11 \mathrm{~km}$ 亿位置する. 東西, 南北とも約 $600 \mathrm{~m}$ の小規模な泥炭地である. 筆者らは女潟を中心として連 続的なつながりを持って形成された泥炭地を便宜上女潟 泥炭地と呼ぶことにする. 女潟泥炭地はヨシやマコモの 湿原植物に代表される低位泥炭地の形態を有し, 現在も 泥炭地中央部に長軸約 $300 \mathrm{~m}$ の開水域安持つ. 女潟泥炭 地は, 丘陵と海岸砂丘にはさむれた凹地に発達した沼沢
化型泥炭地といえる.

女潟泥炭地の周辺は，それを取りまく孤立丘陵と沖積 低地扮よび海岸砂丘に分けられる。孤立丘陵注々の北方 に位置する牛坂丘陵とともにいずれも更新統潟西層より 成り，海抜高度はおおむね $100 \mathrm{~m}$ 学越えない，馬踏川お よび新城川流域の沖積低地は前面学海岸砂丘により封じ られ，各々の河川は曲流し自然堤防を形成する.

浜堤・海岸砂丘汪形態・形成期において三つに区別さ れる. 浜堤 - 海岸砂丘 I は横列砂丘の形態を有し, 浜堤 および浜堤から発達した砂丘と堤間湿地の列が現海岸線

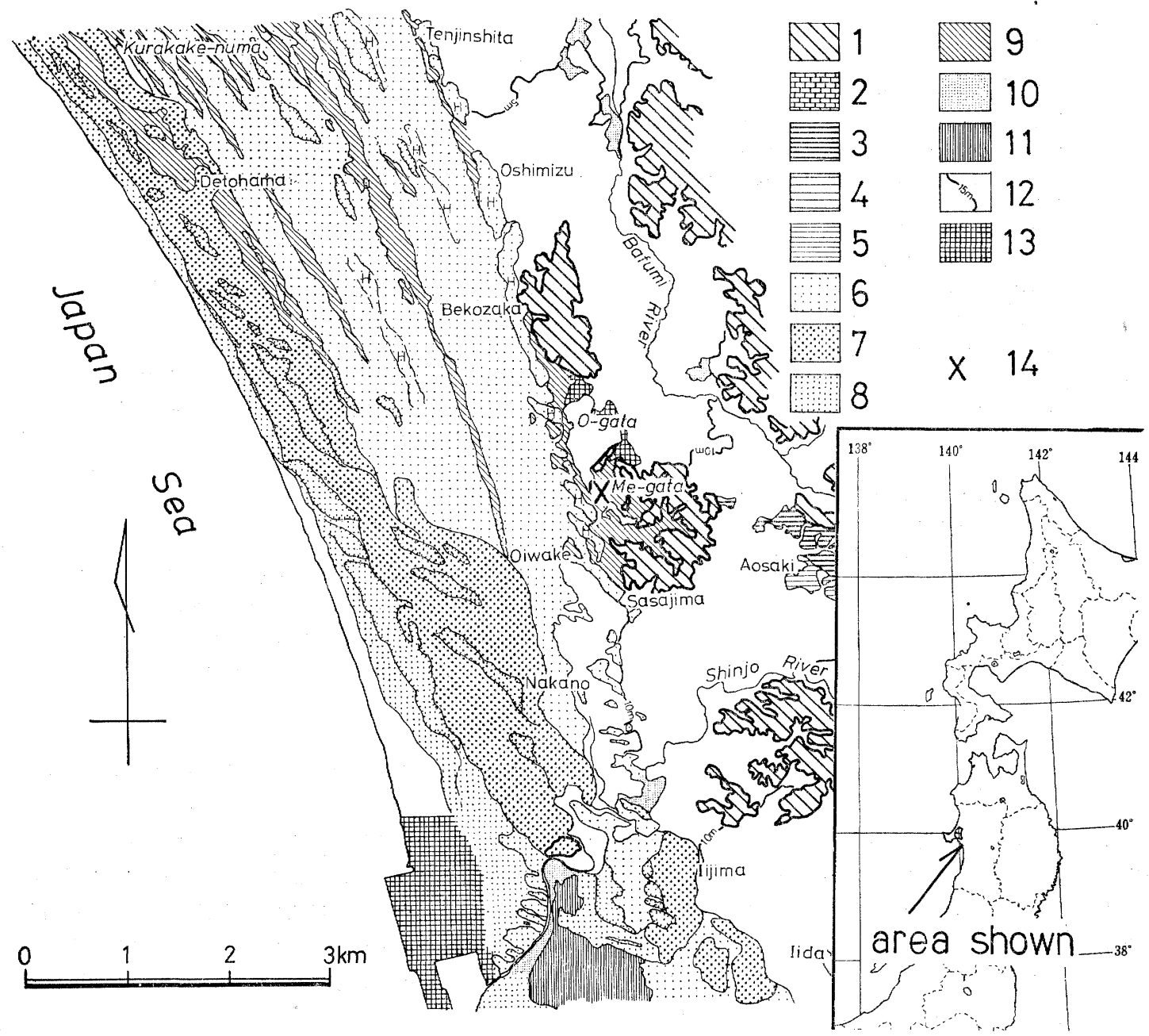

Fig. 1 Geographical map around the Megata peatland (drawn by Dr. Nakata). 1: Hills, 2: River terrace I, 3: River terrace II , 4: River terrace III, 5: River terrace IV, 6: Beach ridge. Coastal dune I, 7: Coastal dune II, 8: Coastal dune III, 9: Back marsh, 10: Natural levee, 11: Abandoned channel, 12: Alluvial plain (Altitudes in meter), 13: Artificial land, 14: The position of the section. 
とほぼ平行に走る。この砂丘形成期の海岸線は，天神下 一大清水一笹島一飯田学結ぶ線付近にあったことが推定 され，この時期に女潟の基盤になった丘陵内の開析谷の 出口は浜堤により閉塞されたと思われる。海岸砂丘II 浜堤・海岸砂丘 I 安覆って形成され北西一南東方向に長 軸を持つ. 海岸砂丘 III は海岸砂丘 II とともに現海岸寄り に発達する新期砂丘で，高度・幅とも旧雄物川河口から 北に遠ざかるに従って減少する (Fig. 1).

女潟および女潟周辺の植生については高田ほか(1974) の詳細な報告がある，泥炭地内の草本植生は，ウキャガ ラーマコモ群集, カサスゲ群集, チゴザサーアゼスゲ群 集，ツルスゲ群落，ニッポンイヌノヒゲ一オオイヌノ八 ナヒゲ群落，エゾノサヤヌカグサ群落，コアゼガヤツり 一カリマタガヤ群落, ウシソシッペイ群落の 8 群落が認 められている，開水域をとりまく泥炭地の大部分はヨ シ，マコモに代表されるウキヤガラーマコモ群集で占め られ，一般には開水域に近い内部でマコモが優占する。 また周辺の森林植生は，レンゲッツジーズミ群集，ハン ノキ林，コナラーカカスミザクラ群集，カシワ林，スギ植
栽林, クロマツ植栽林, アカマツ植栽林を認めている. 女潟西方の砂丘はクロマツ植栽林で被われる。一方，東 方の潟西層より成る丘陵上はスギ植栽林，アカマツ植栽 林，コナラ林，カシワ林によって占められる. 周辺の森 林と湿原との境には自然植生に近いハンノキ林とレンゲ ツツジーズミ低木林が認められるが，これらを除いて周 辺森林植生は人為的影響を強く受けている.

\section{III. 試料および方法}

試料の採取は開水域北辺の丘陵から約 $200 \mathrm{~m}$ の地点で 行なった. 柱状試料はヒラー式ボーラを用いて採取し， 全長 $630 \mathrm{~cm}$ の試料が得られた。

試料の最下部 $630-580 \mathrm{~cm}$ は兏褐色分ら兏白色の細粒 シルトで構成され植物遺体を核とえど含まない. $580 \mathrm{~cm}$ 近くではわずかに砂粒を混じえ，それ以上ではわずかに 分解した泥炭に移行する.この泥炭は無数の大型植物遺 体で構成される. $490 \mathrm{~cm}$ では厚さ $2 \mathrm{~cm}$ の灰褐色粘土層 が入る. $390 \mathrm{~cm}$ 付近では $3 \sim 5 \mathrm{~cm}$ の細長い硬質の根が 多数見出される.これより上部ではミズゴケ泥炭となり
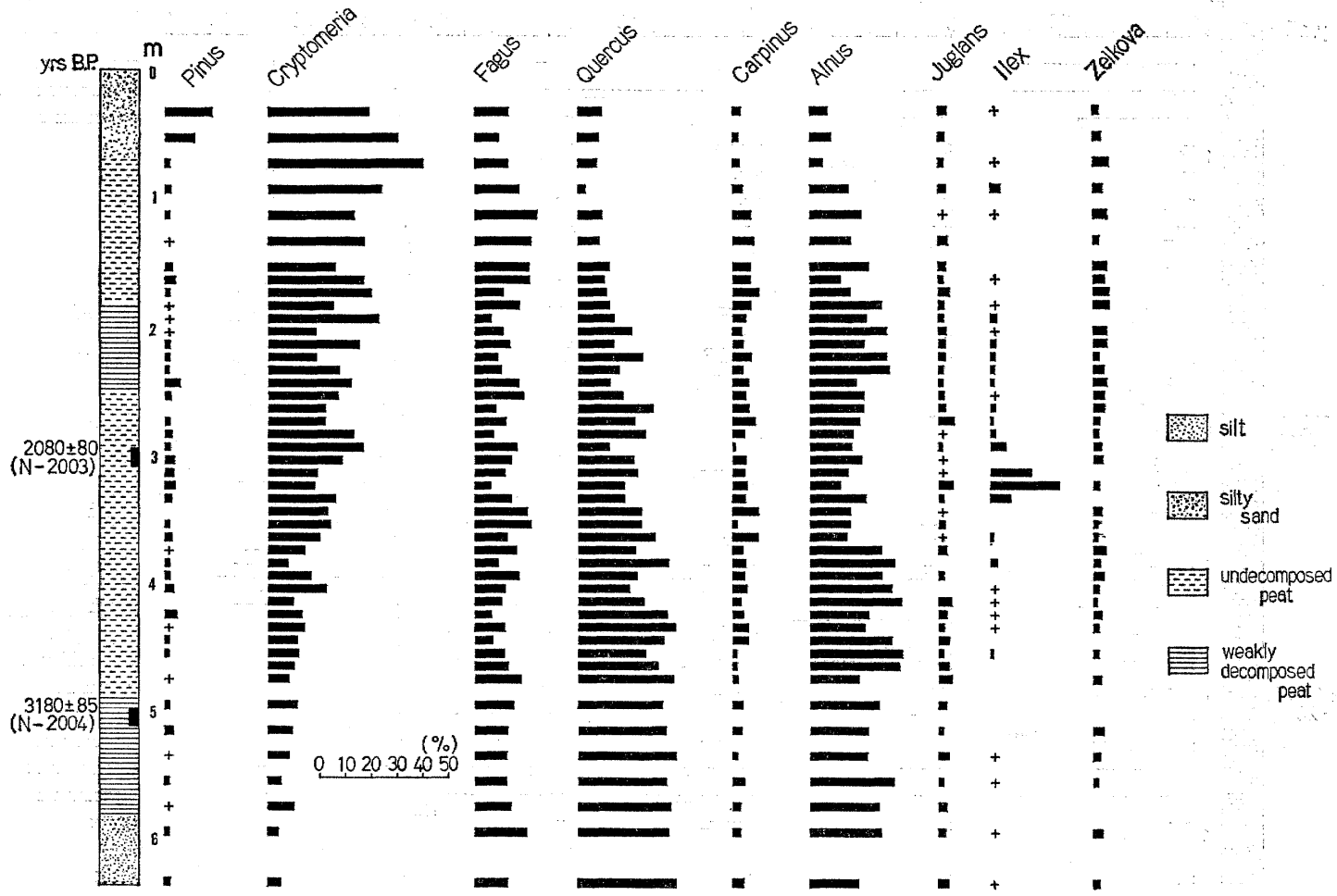

Fig. 2 The diagram of arboreal pollen of the peat profile from the Megata peatland. (the percentages are calculated on the total arboreal pollen) 
組織は緻密で黒褐色を呈する。これは $190 \mathrm{~cm}$ 位まで連 続する. 途中 $250 \mathrm{~cm}$ では粗粒砂がゴマシオ状に入り, それとともに硬質の根が多数認められる． $250-130 \mathrm{~cm}$ では泥炭の分解が比較的進えでいる. $190-70 \mathrm{~cm}$ 位末 ではイネ科植物遺体を主とする泥炭に移行する。しかし $70 \mathrm{~cm}$ 以上では上部に行くに従って粗精砂が多くなり, $20 \mathrm{~cm}$ から地表まで㤬黒褐色砂層に変わる.

深さ $300 \mathrm{~cm}$ 打よび $500 \mathrm{~cm}$ の 2 点に扔いて約 $200 \mathrm{~g}$ の泥炭試料を得, 日本アイソトープ協会（測定責任者, 浜田氏）によって ${ }^{14} \mathrm{C}$ 年代測定が行なわれ下記の測定值 它得を。

$$
\begin{array}{ll}
300 \mathrm{~cm} & 2,080 \pm 80 \text { y.B.P. }(\mathrm{N}-2003) \\
500 \mathrm{~cm} & 3,180 \pm 85 \text { y.B.P. }(\mathrm{N}-2004)
\end{array}
$$

表層より $10 \mathrm{~cm}$ ごとに柱状試料の内部范約 $1 \mathrm{~g}$ 切り 取り, $10 \% \mathrm{KOH}$ 処理からアセトリシス 処理恣経て, シルトに富むものは HF 処理を行ない最後にグリセリ ンで封入し検鏡用スライドとした．検鏡は一枚のプレパ
ラート全面について行ない, 400〜800 個の花粉・胞子を 観察し各々の同定を行なった。同定し得た各科扔よび属 の花粉・胞子，未同定の個体は注とえど単体標本として 保存した. 花粉. 胞子の出現率は全木本性花粉数 (200個 以上）窙数として百分率で求めた.

\section{IV. 花粉分析の結果}

検鏡の結果，科または属まで同定できたものは Abies， Tsuga, Pinus, Cryptomeria, Fagus, Quercus, Castanea, Carpinus, Betula, Corylus, Alnus, Zelkova, Salix, Myrica, Juglans, Pterocarya, Rhus, Ilex, Acer, Aesculus, Fraximus, Sapium, Sorbus, Weigela, Viburnum, Sambucus, Vitis, Ericaceae, Moraceae, Rutaceae, Araliaceae の木本性花粉, Artemisia, Rumex, Polygonum, Sanguisorba, Menyanthes, Trapa, Typha, Galium, Potamogeton, Nymphaea, Thalictrum, Drosera, Haloragaceae, Gramineae, Cyperaceae, Iridaceae, Liliaceae, Hydrocharitaceae, Compositae,
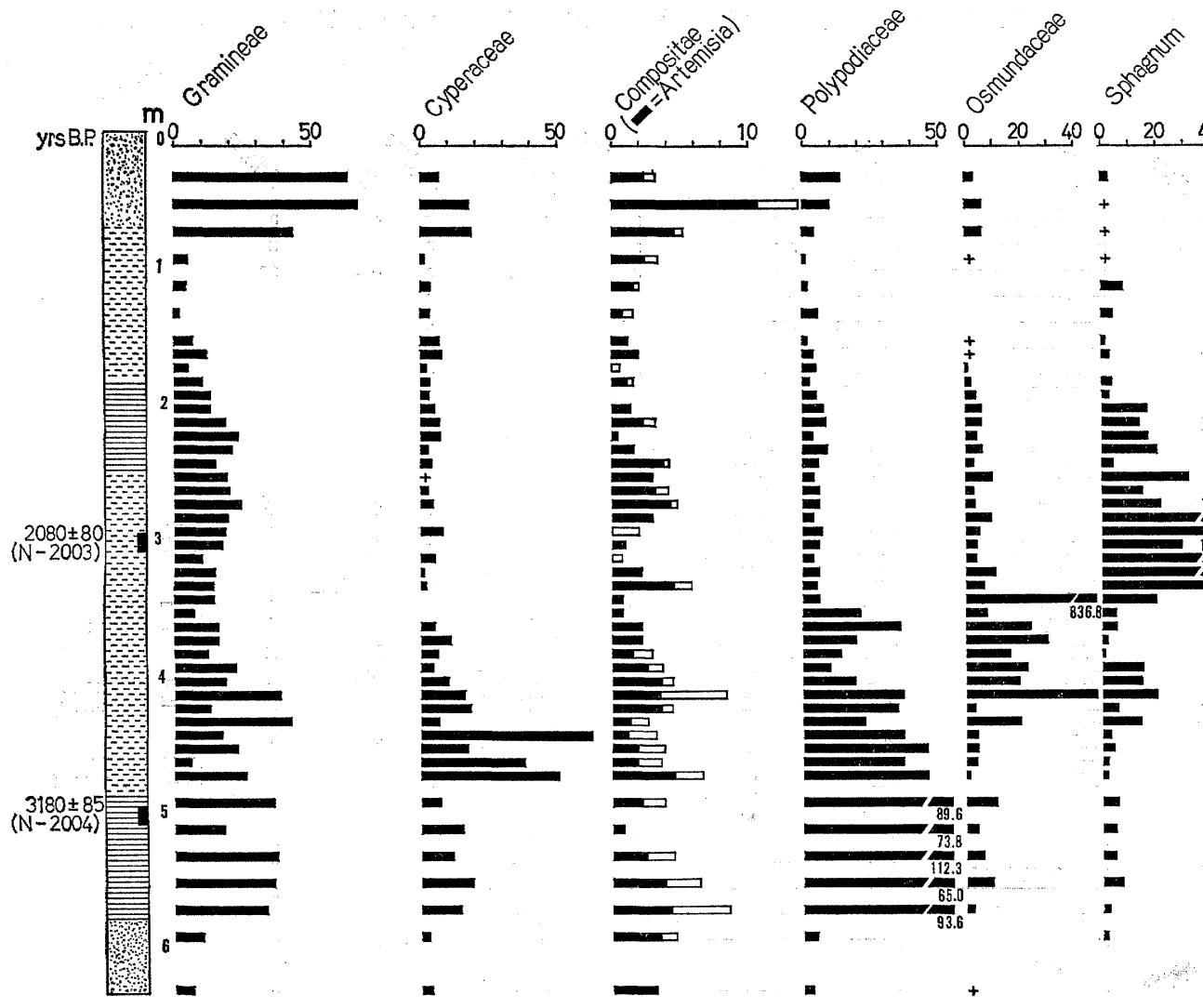

NAP,Total Pollen
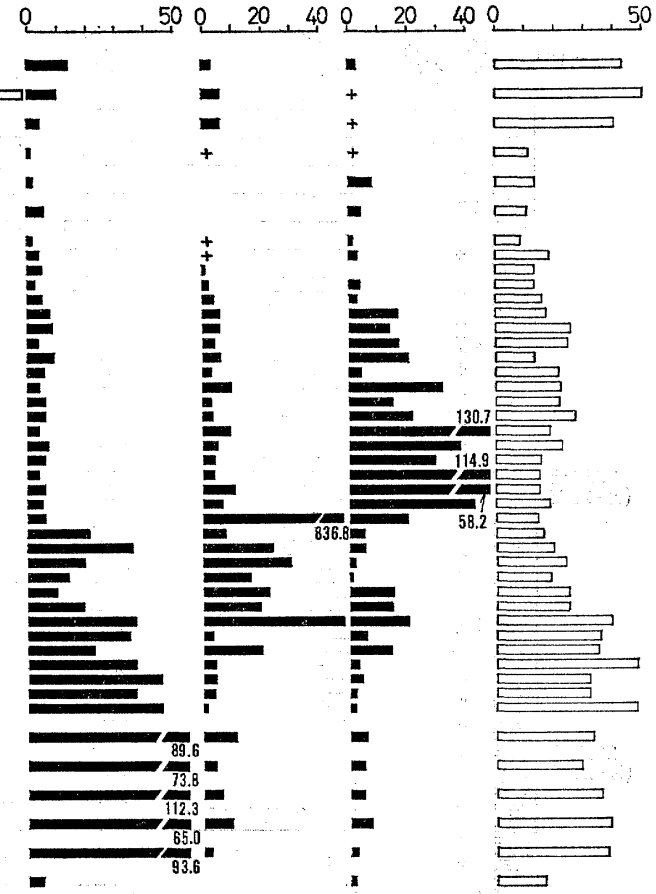

$\square$

-

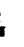

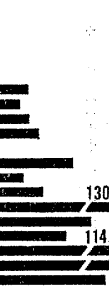

$\square$

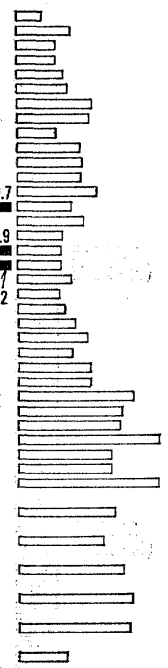

Fig. 3 The diagram of non-arboreal pollen and spores of the peat profile from the Megata peatland. (the percentages are calculated on the total arboreal pollen) 
Umbelliferae, Ranunculaceae, Lythraceae, Leguminosae, の草本性花粉, および, Polypodiaceae, Osmundaceae, Sphagnum, Botryococcus, Concentricystes の羊歯類, 蘚菌類, 藻類胞子であった。

Fig. 2，3 に主要な花粉・胞子の消脣を示し, Fig. 4 には低率で連続的に出現する草本性花粉の消長を示す.

この花粉分布図から，主に主要木本性花粉の消長をもと にして次の 3 つの花粉帯に区分できる.

I ) Fagus-Quercus-Alnus 帯 $(630-420 \mathrm{~cm})$

II) Cryptomeria-Fagus-Quercus-Alnus 带 (420-70 $\mathrm{cm}$ )

III) Pinus-Cryptomeria-Alnus 带 $(70-0 \mathrm{~cm})$

深さ $300 \mathrm{~cm}$ および $500 \mathrm{~cm}$ の年代は各々 $2,080 \pm 80$

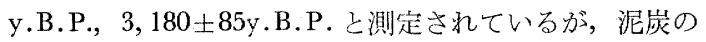
堆積速度が应ぼ均一であると仅定すると，I带下限は約 $3,500 \mathrm{y} . \mathrm{B} . P$. ないしそれ以上，I带下限は約 $2,700 \mathrm{y}$. B.P., た， I 帯下限は約 1,000 y, B.P. と推定され る.
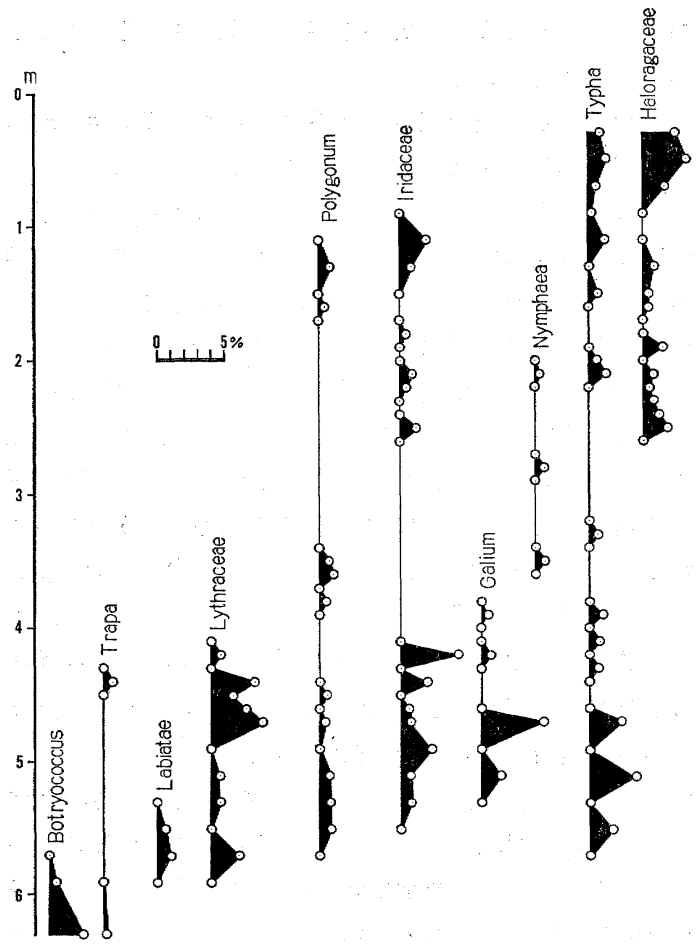

Fig. 4 The diagram of non-arboreal pollen and spores with a low frequency of the peat profile from the Megata peatland. (the percentages are calculated on the total arboreal pollen)

\section{a) $\mathbf{I}$ 帯}

Quercus, Alnus の優勢によって特徵づけられる.Quercus は 30-40\%, Alnus も上部でわずかに高くなるがお お光称20-30\%定し，両属ともこの花粉带它通して大 きな変化は見られない。Cryptomeria は $20 \%$ に満たない が上部入の增加が認められる.Pinus の出現は断片的で あり $5 \%$ に満たない. 草本性花粉·胞子ではGramineae, Gyperaceae, Polypodiaceae の高率の出現で特徵づけら れる。これらの出現率は花粉帯を通して著しい变化を示 し次の 3 つの亜帯に区分できる.

I-a 亚带 $(630-590 \mathrm{~cm})$ ：黄藻類 Botryococcus の出 現によって特徴づけられる. 草本性花粉および羊歯・蘚 苔類胞子の出現が木本性花粉に比して極めてそしく，\& た全花粉の中で草本性花粉の占める割合は $15 \%$ 前後で 極めて低い，低率ながら Trapa が見出される。

I-b 亜带 $(590-480 \mathrm{~cm})$ : Gramineae, Cyperaceae, Polypodiaceae の急激な増加によって特徵づけられる. 低率であるが Labiatae の出現は，この亜帯を特徴づけ る.なた Lythraceae, Polygonum, Iridaceae, Galium, Typhaはこの亜带より出現しはじ內る. 全花粉に対して 草本性花粉の上める割合洼 30 - $40 \%$ 亿増加する.

Polypodiaceae は 65\% から最高 112\%の高率を示し 極めて顕著である. Compositae は下部で $8 \%$ 以上を示 すが次第に低下する.Artemisiaの占める割合は比較的低

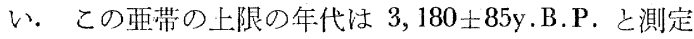
されている.

I-c 亜宜 $(480-420 \mathrm{~cm})$ : Cyperaceae の高率の出現 で特徽づけられる. Polypodiaceae はこの亜带に入って 低下与るが依然として 40\% 前後を示し他に比べその出 現は著しい. Lythraceae はこの带帯で出現が著しく4 $\%$ 近く定示守.

\section{b) II 带}

Cryptomeria, Quercus, Alnus の優勢な花粉带である. Quercus の出現率屿次第に低下し上部では $10 \%$ 以下と なる。乙れに対し下部で低率を示した Cryptomeria は次 第に出現率を高め上部では 40\% 前後に達する.Fagus は I 带と比して大きな変化を示さない。地表下 $320 \mathrm{~cm}$ 前 後でIlex の急な増加があり $30 \%$ 前後に及ぶ. この花

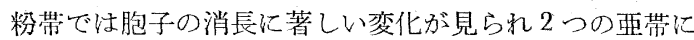
区分できる.

II - $\mathrm{a}$ 亜带 $(420-330 \mathrm{~cm}):$ Osmundaceae の高率の 出現によって特徵づけられる.

Polypodiaceae は下部および中部で依然高率を示すが 上部では急激な低下が見られ 10\% 以下となる.Poly- 
gonum, Galium, Nymphaea, Typha が低率で出現する.

II-b 亜带 $(330-70 \mathrm{~cm}):$ Sphagnum の急激な増加が 認められ，約 60-130\%の高率を示しこの亜帯究特徴づ ける. Osmundaceae は衰退する. 地表下 $200 \mathrm{~cm}$ 前後 を境に Sphagnum の出現率は 5\% 以下となり衰退の傾向 をたどる・高率で連続的に出現していた Gramineae や Cyperaceae, Polypodiaceae, Osmundaceae 屯同様の傾 向が認められる. Polygonum, Iridaceae, Typha, Haloragaceae は中〜上部で連続的な出現它示す. この西带 の上部の年代は $2,080 \pm 80$ y.B.P. と測定されている.

\section{c) III 带}

Pinus, Cryptomeria が極めて優勢となりこの帯を特徵 づける。I，正帯では 5\%に満たなかったPinus は 10\% 以上に増加する.Fagus, Quercus, Alnus 等の落葉広葉樹 の出現率は全層を通して最も低くなる。草本性花粉では Gramineae, Cyperaceae, Compositae (Artemisia) の高 率の出現が特徵的である。ことに Gramineae は上部で 60\% 以上の高率を示す. Polypodiaceae, Osmundaceae, Sphagnum といった羊歯・蘚苔類胞子の出現率はわずか に高まるが草本性花粉汪どに著しくはない。

\section{v. 考察}

先づ木本性花粉の消長をもとにして泥炭地周辺の過去 の森林植生について考えて夕る. 女潟泥炭地堆積物の全 層を通して，木本性花粉の消長は Cryptomeria，Fagus， Quercus, Alnus の優勢と Cryptomeria の出現率の漸次的 な増加によって特徴ゔけられる. I 帯では Fagus, Quercus, Alnusが優占し，ミズナラ・ブナ林もしくはブナ． ミズナラ林に近い森林が存在していたと考えられる．II 带では Fagus, Quercus, Alnus とともにCryptomeria が 優勢となるが，高率で出現するこれらの属によって構成 される森林は一般にスギを優占種としたスギ・ブナ林が 考えられる. 現在のスギ・ブナ林は高度により構成上の 差異が認められ，700〜 800m の山地带に立地するもの はキタゴヨウを多く混じえるが，これに対し $200 〜 400 \mathrm{~m}$ の比較的低い地域のスギ・ブナ林はこれ学欠く、II带に 占けるPinus の出現率は極めて低くかつ断片的である. このことは現在比較的低い地域に分有するスギ・ブナ林 が负潟周辺にも，広く分布ししていたこと示唆してお り，同時に現在秋田県北部および東部などに見られるス ギ・ブナ林（交化庁，1970）が残存植生である可能性安 支持するものである. 全層壳通して Alnus の出現が著し いが，沼沢化にともなって女潟周辺に成立したハンノキ 林が今日まで存続した結果と芳えられよう。四帯にお
ける Pinus の増加および落葉広葉樹の出現率の低下は， 人為的な森林破壊による丘陵地の裸地化と, そ秃にとも なうアカマツ林の拡大によってもたらされたと考光られ る. 近世に打ける海岸砂斥上のクロマツの植栽の影響も 無視できないであるう。

Cryptomeria は最下部より連続的に出現し，その出現 率の上部への漸次的な増加が認められる。福島県赤井谷 地湿原 (海抜 $521 \mathrm{~m}$, 北緯 $37^{\circ} 31^{\prime}$, 東経 $140^{\circ}$ ) に打い ても約 6,500 y.B.P. 以降連続的な出現が認められ，中 部ではそのピークが確認される（Soнma，1961，折笹。 鈴木，1968). 現生のスギは水という単数の要素によっ てその分布が鋭敏に左在され，Cryptomeria の増加が降 水量の增加等によって，引き起こされたことが予想され る. Cryptomeria の增加しはじめる時期は泥炭堆積開始 の時期にもあたり，このことは阪口(1961)等の気候の湿 㵎化という考学支持するものとも思われる。しかし， 今日においても堆積物中の花粉の出現率の定向的な地史 的変化が群落の構成種の量的な变化をいかに示すかにつ いて充分な資料を欠く．この地域の群落の地史的遷移の 特性は，詳細な多くの資料を待って検討されることが妥 当のように思われる.

泥炭地内部の湿原植生の变遷は, 各々の草本性花粉の 出現率の明瞭な変化によって示される. 最下部のシルト 中には植物遺体は添とえど含立れず，また草本性花粉・ 胞子の出現率も極わて低い。この時期は女潟泥炭地発達 の初期にあたり，水域の植物に乏しい沼沢地であったと 思われる. 泥炭の堆積および Gramineae, Cyperaceae, Polypodiaceae の出現率の増加は，その後の地下水面の 低下もしくは沼沢地水面の低下等いわゆる気候の冷涼化 によって引き起こされたものであろう．泥炭の堆積が更 に順調に進行すれば泥炭地は中間泥炭地への移行を促さ れるが，II 帯に括ける Osmundaceae, Sphagnum の出 現率の急增はその移行を示すものであるう。しかし， I 一b 亜带に出ける Gramineae, Cyperaceae, Sphagnum の出現率の低下および Iridaceae, Haloragaceae, Typha の出現の開始, さらに更帯に抢ける Gramineae, Gyperaceae, Haloragaceae, Artemisia の出現率の急激な増 加は泥炭地の荒地化を示す一連の植生变化と見ることが でき，ことに II 帯の急激な变化は森林破壤にともなう侵 食土壤の泥炭地への供給・堆積が著しくなったことを示 唆与るものであろう.そうした土壤の堆積は泥炭地の水 面の上昇をもたらし現在見るようなウキヤガラ一マコモ 群集の拡大学促したと考えられる。

以上女潟泥炭地およびその周辺の原植生ならびに植生 
変遷について若干の考察を行なったが，花粉組成の変化 をもたらす環境要因は極めて複雑であり，泥炭地内部構 造やその他地形環境との関係が究明されなければならな いが，これら注今後の課題としておきたい。

\section{謝 辞}

本報を終えるにあたり，研究の機会を与えられた秋田 県教育委員会に厚くお礼申し上げる. 東北大学地理学教 室中田高博士にはともに現地に赴かれ地形について御教 示頂き本報のために地形区分図の呈示を承諾下さった。 秋田大学生物学教室加藤君雄教授に注地において何か と便宜を計って下さった. 日本大学交理学部遠藤邦彦先 生には原稿を読えで頂き有益な御意見を賜わった。以上 の方々に記してお礼申し上げる。

\section{引用文 献}

交 化 庁 (1970) 天然記念物緊急調查, 植生図·主要動
植物地図，秋田県.

堀 正一 (1959) 青森県龟岡遺跡の花粉分析, 「亀ケ 岡遺跡——青森県䁆ヶ岡低湿地遺跡の研究—」, 147 -148 .

神保忠男（1965）日本の花粉学の現在と将来. 第四紀研 究， 4, 113-115.

折笠常弘・鈴木敬治 (1968) 福島県赤井谷地泥炭層の ${ }^{14} \mathrm{G}$ 年代, 地球科学, 22, 39.

阪口豊 (1961) 北日本の完新世の気候変化. 地理評, 34, 259-268.

Sohma, K. (1961) Pollen analysis of the peat at Akaiyachi moor, Fukushima Prefecture. Ecol. Rev., 15, 127130.

高田 順·越前谷康 - 高橋祥祐 - 望月陸夫 (1974) 秋田 市金足女潟の植生. 秋田自然史研究会, $32 \mathrm{p}$.

山崎次男 (1954) 花粉分析法による秋田スギの成因に関 する考察. 日本林学会誌, 36, 134-137. 
Plate Photographs of the pollen grains of the main genera.

All $\times 1000$. ( ) = The number of the single-grain pollen preparats.

1, 2 Cryptomeria from $190 \mathrm{~cm}$ (ST-234)

3,4 Alnus from $190 \mathrm{~cm}$ (ST-215)

5, 6 Alnus from $190 \mathrm{~cm}$ (ST-219)

$7-10$ Quercus from $270 \mathrm{~cm}$ (ST-247)

11,12 Quercus from $190 \mathrm{~cm}$ (ST-246)

13, 14 Fagus from $270 \mathrm{~cm}$ (ST-227)

15, 16 Fagus from $100 \mathrm{~cm}$ (ST-224) 

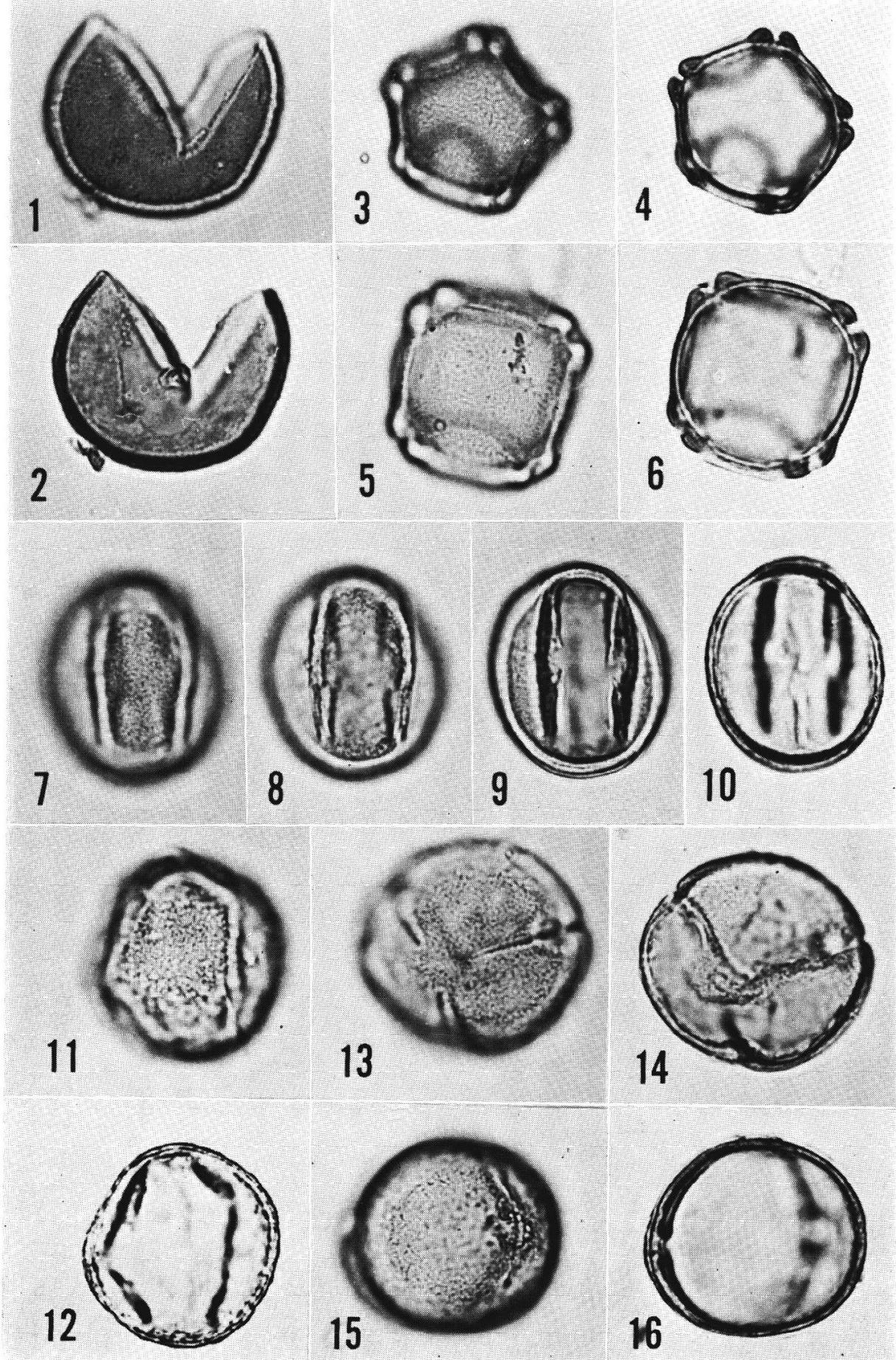